\title{
Decreased $\mathrm{GABA}_{\mathrm{A}}$ receptor subunit mRNA concentrations following chronic lorazepam administration
}

\author{
Inwha Kang \& ${ }^{1}$ Lawrence G. Miller \\ Division of Clinical Pharmacology, Depts. of Psychiatry and Pharmacology, Tufts Univ. School of Medicine and New England \\ Medical Center, Boston, MA, U.S.A.
}

\begin{abstract}
Chronic benzodiazepine administration has been associated with alterations in binding and function at the $\mathrm{GABA}_{\mathrm{A}}$ receptor. To evaluate effects of chronic benzodiazepine exposure on messenger RNA (mRNA) concentrations for several $\mathrm{GABA}_{\mathrm{A}}$ receptor subunits, we treated mice with lorazepam, $2 \mathrm{mg} \mathrm{kg}^{-1}$ daily for 1-28 days and evaluated mRNAs for the alpha1 and gamma2 subunits by Northern hybridization. In cerebral cortex, concentrations of mRNA for the alpha1 and gamma2 subunits were unchanged from vehicle or control after 1-10 days of lorazepam. However, after 14 days of treatment mRNA concentrations for both subunits decreased to approximately $50 \%$ of control values and remained decreased at 28 days. In contrast, no significant alterations were observed for either subunit mRNA in hippocampus or cerebellum over the same time course. Alterations in mRNAs in cortex occur after the development of tolerance and receptor downregulation in this model.
\end{abstract}

Keywords: GABA $_{\mathrm{A}}$ receptor; alpha1 subunit; gamma2 subunit; benzodiazepine; chloride

Introduction Both behavioural and neurochemical alterations have been observed during chronic benzodiazepine administration in animals. For most effects of benzodiazepines, tolerance occurs and may limit the clinical utility of these compounds (Greenblatt \& Shader, 1978). Although differing neurochemical alterations have been reported by several investigators, several recent studies indicate decreases in benzodiazepine receptor binding and $\mathbf{G A B A}_{\mathbf{A}}$ receptor function associated with chronic benzodiazepine administration (Tietz et al., 1986; Miller et al., 1988; 1989; Marley \& Gallager, 1989).

Benzodiazepines exert their effects in the central nervous system binding to a specific site located on the $\mathrm{GABA}_{\mathrm{A}}$ receptor complex (Olsen \& Tobin, 1990). Several subunits of the GABA $_{\mathrm{A}}$ receptor have been cloned and sequenced in the past several years (e.g., Schofield et al., 1987; Pritchett et al., 1989). Although the receptor structure remains uncertain, and indeed may vary among brain regions, it is likely to be a heteroligomeric protein including alpha, beta, gamma, and possibly delta polypeptide subunits (Olsen \& Tobin, 1990).

In view of the alterations in receptor binding and function observed during chronic benzodiazepine administration, we evaluated mRNA concentrations for the most abundant subunits, alpha1 and gamma2, in three brain regions to assess their relation to receptor alterations.

Methods Drug administration Lorazepam $\left(2 \mathrm{mg} \mathrm{kg}^{-1}\right.$ daily) was dissolved in PEG400, placed in Alzet 2001/2002 pumps, and implanted subcutaneously in mice under brief ether anaesthesia. This regimen has been shown to produce constant drug concentrations in plasma and brain, behavioural tolerance, and receptor downregulation (Miller et al., 1988). Control mice received vehicle only.

RNA isolation and Northern hybridization Total RNA was isolated as previously described (Auffray \& Rougeon, 1980). RNA was electrophoresed on agarose $(1.2 \%)$ gels containing $2.2 \mathrm{M}$ formaldehyde, then transferred to nylon membranes. After prehybridization for $1 \mathrm{~h}$, membranes were hybridized at $42^{\circ} \mathrm{C}$ overnight with ${ }^{32} \mathrm{P}$-labelled DNA probes $\left(5-10 \times 10^{6}\right.$ c.p.m., approximately $3 \mathrm{ng} \mathrm{ml}^{-1}$ ). After washing at $42^{\circ} \mathrm{C}$, membranes were exposed to X-ray film at $-80^{\circ} \mathrm{C}$ for $1-3$ days. To test for possible interlane variability and nonspecific effects,

\footnotetext{
${ }^{1}$ Author for correspondence at: Box 1007, New England Medical Center, 750 Washington St., Boston, MA 02111, U.S.A.
}

membranes were subsequently washed and reprobed with ${ }^{32}$ P-labelled glyceraldehyde-3-phosphate dehydrogenase (GAPDH) RNA. Based on $18 \mathrm{~S}$ and 28S ribosomal RNA, alpha1 hydribization occurred at $4.5 \mathrm{~kb}$, gamma2 at $4.4 \mathrm{~kb}$, and GAPDH at $1.1 \mathrm{~kb}$. Results were quantitated by densitometry (LKB Ultroscan) with linearity assessed by ${ }^{32} \mathrm{P}$ standards.

Probes and probe preparation Oligonucleotide probes were synthesized based on the first 45 transcribed bases of the reported alpha1 and gamma2 sequences (Schofield et al., 1987; Pritchett et al., 1989). For GAPDH, a riboprobe was generated from a cDNA human clone provided by Dr D. Chikaraishi. Oligonucleotide probes were $5^{\prime}$ end-labelled with ${ }^{32} \mathrm{P}$ by use of $\mathrm{T} 4$ polynucleotide kinase.

Data analysis Results are presented as relative units. For each blot, control RNA from an untreated animal was included. Units were determined as subunit density corrected for GAPDH density (subunit/GAPDH), in turn divided by control density (control/GAPDH). Data were analyzed by analysis of variance with Dunnett's test.

Results Treatment of mice for $1,2,4,7$, and 10 days with lorazepam did not alter concentrations of alpha1 subunit mRNA in cortex (Figure 1a, b). However, after 14 days of exposure, mRNA concentrations were decreased to approximately $50 \%$ of vehicle or shorter treatment levels. This decrement persisted in animals treated with lorazepam for 28 days. Similar results were observed for the gamma2 subunit in cortex (Figure 1a, b). Concentrations of mRNA were not altered from 1 to 10 days, but were decreased by about $50 \%$ after 14 days of lorazepam exposure. This decrement also persisted at 28 days of treatment. Neither alpha1 nor gamma2 subunit mRNAs were altered by vehicle exposure.

In hippocampus, concentrations of mRNA for both the alpha1 and gamma2 subunits were not significantly altered at 14 and 28 days compared to 1 and 7 days of lorazepam administration (Figure 2). In cerebellum, concentrations of mRNA for both alpha1 and gamma2 subunits remained unchanged from 1 to 28 days (Figure 2). In both hippocampus and cerebellum, vehicle administration did not alter either alpha1 or gamma2 mRNA.

Discussion These data indicate that mRNAs for two GABA receptor subunits, alpha1 and gamma2, are decreased in 
a
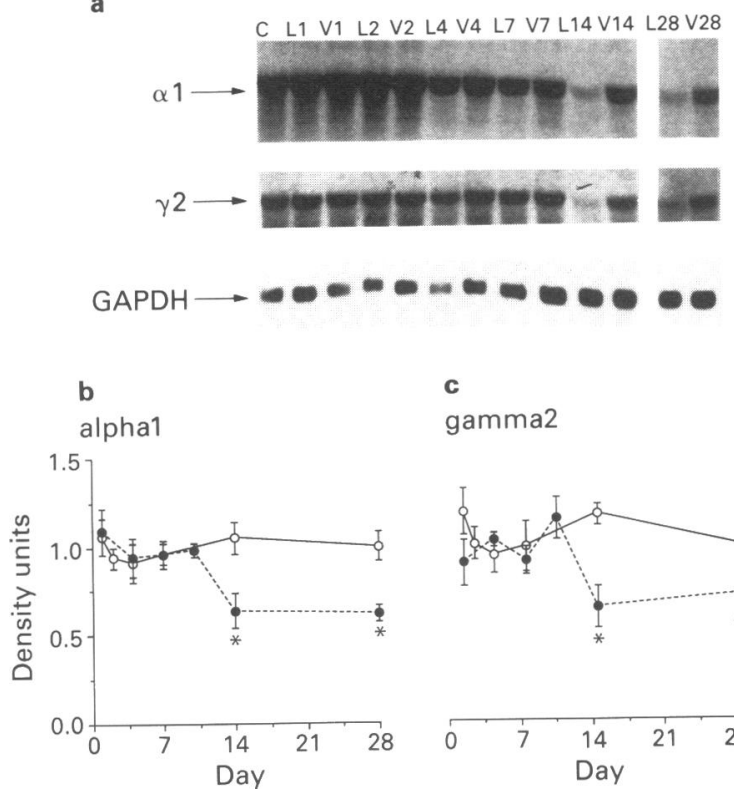

c

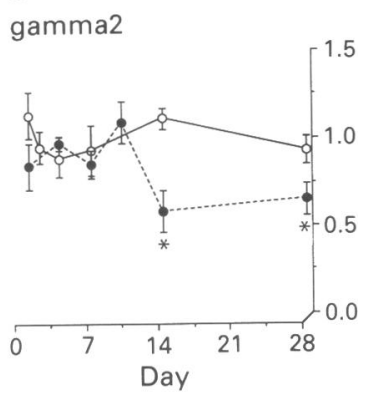

Figure 1 Effects of lorazepam and vehicle administration on alpha1 and gamma2 subunit mRNA concentrations in cortex. Mice were treated with lorazepam ( $2 \mathrm{mg} \mathrm{kg}^{-1}$ daily) or vehicle as described, and mRNA concentrations determined by Northern hybridization. (a) Northern hybridization. Results are from a representative hybridization repeated 2-3 times, from an experiment repeated three times. $\mathrm{C}=$ control, $\mathrm{L} 1$ = day 1 lorazepam, $\mathrm{V} 1$ = day 1 vehicle, etc. (b) Relative mRNA concentrations. The left panel is alpha1 mRNA and the right panel is gamma2 mRNA. Autoradiographs were analyzed by densitometry in arbitrary absorbance units. (O) Vehicle treatment; (O) lorazepam treatment. Results are mean, s.e.mean shown by vertical bars, $n=2-3$ determinations each from 3 separate experiments. Units are sample absorbance/GAPDH absorbance. ${ }^{*} P<0.05$ vs. vehicle. There are no significant differences among vehicle treatments.

cortex by chronic lorazepam administration. This effect appears to be due to benzodiazepine exposure: treatment with vehicle only does not produce any changes in mRNA concentrations. In addition, a control mRNA coding for GAPDH is unaffected by lorazepam treatment. Additional evidence for the specificity of this effect derives from regional studies. Concentrations of mRNA for these subunits are decreased in cortex but not hippocampus or cerebellum. It is also notable that mRNA concentrations for the alpha1 and gamma2 subunits are altered in parallel.

For lorazepam at the dose used in this study, receptor binding and function in cortex are decreased after 7 days (Miller et al., 1988), but the mRNA concentrations in cortex remain unchanged at 7 days; decrements do not occur until 14 days. In addition, the regional specificity of changes in binding and receptor function differed from alterations in mRNAs. Benzodiazepine binding and GABA-dependent chloride uptake were decreased in hippocampus and unchanged in cerebellum during chronic lorazepam administration (Miller
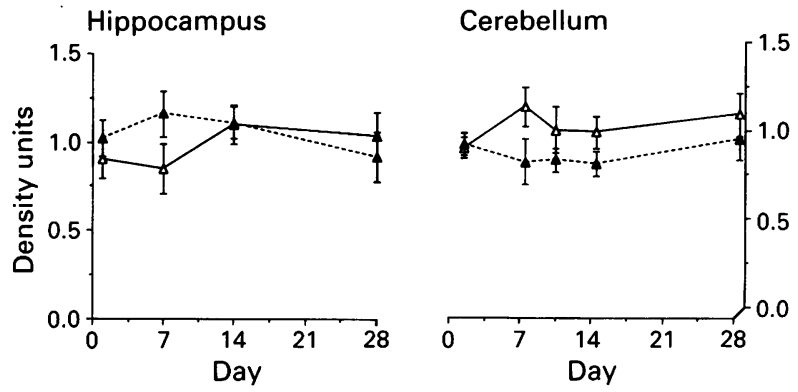

Figure 2 Effects of lorazepam administration on alpha1 and gamma2 subunit mRNA concentrations in hippocampus and cerebellum. Mice were treated with lorazepam $\left(2 \mathrm{mg} \mathrm{kg}^{-1}\right.$, daily) and mRNA concentrations determined by Northern hybridization: $(\Delta)$ alphal mRNA; (A) gamma2 mRNA. Results are mean, s.e.mean shown by vertical bars, $n=2-3$ determinations each from 2 separate experiments. Units are sample absorbance/GAPDH absorbance. There are no significant differences among mRNA concentrations.

et al., 1988). Thus, the later onset for changes in mRNA compared to receptor effects may indicate that mRNA alterations do not account for initial receptor downregulation. It is possible that reductions in mRNA concentrations in cortex help to sustain receptor downregulation observed at 14 days. Receptor alterations in the absence of mRNA changes in hippocampus also suggest that genetic and receptor effects are unrelated. An alternative hypothesis is that both binding and mRNA alterations in regions such as hippocampus may be heterogeneous and thus not always evident in regional tissue samples.

One preliminary report has assessed alphal mRNA during chronic benzodiazepine administration (Heninger et al., 1989). In this study, rats received diazepam by intermittent injection for 3 weeks. Decreases in alpha subunit mRNA, apparently alpha1, were observed in cortex at this time. Thus, results in a similar but not identical system corroborate the alterations observed in the present study. Our results extend the prior study to the gamma2 subunit, to a detailed time course, and to several brain regions.

A number of neurotransmitter receptors and ion channels exist as multiple subtypes, apparently by the use of distinct genes to encode receptor subunits polypeptides (Olsen \& Tobin, 1990). Such heterogeneity may contribute to increased information-processing ability among neurones. Differential regulation of expression of these subunits might also modulate responses to drugs or other stimuli. Our results indicate that several $\mathrm{GABA}_{\mathrm{A}}$ receptor subunit mRNAs are affected by chronic administration of a ligand which binds to this receptor. This alteration may help to modulate chronic effects of xenobiotics.

Supported in part by grants DA-05258 and MH-34223 from the U.S. Public Health service. L.G.M. is the recipient of a Faculty Development Award in Clinical Pharmacology from the Pharmaceutical Manufacturers Association Foundation.

\section{References}

AUfFray, C. \& ROUGEON, F. (1980). Purification of mouse immunoglobulin heavy-chain messenger RNAs from total myeloma tumor RNA. Eur. J. Biochem., 107, 303-314.

GREENBLATT, D.J. \& SHADER, R.I. (1978). Dependence, tolerance and addiction to benzodiazepines: clinical and pharmacokinetic considerations. Drug Metab. Rev., 8, 13-28.

HENINGER, C., SAITO, N., TALLMAN, J.F., DUMAN, R.S., GARRETT, K.M., VITEK, M.P. \& GALLAGER, D.W. (1989). Effects of continuous diazepam administration on GABA-A subunit $m R$ NA in rat brain. Soc. Neurosci. Abs., 831.

MARLEY, R.J. \& GALLAGHER, D.W. (1989). Chronic diazepam treatment produces regionally specific changes in GABA-stimulated chloride influx. Eur. J. Pharmacol., 159, 217-223.

MILLER, L.G., GREENBLATT, D.J., BARNHILL, J.G. \& SHADER, R.I. (1988). Chronic benzodiazepine administration: I. Tolerance is associated with downregulation of benzodiazepine receptor

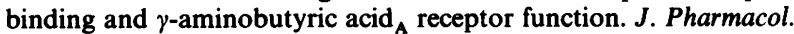
Exp. Ther., 246, 170-176.

MILLER, L.G., WOOLVERTON, S., GREENBLATT, D.J., LOPEZ, F., ROY, R.B. \& SHADER, R.I. (1989). Chronic benzodiazepine administration. IV. Rapid development of tolerance and receptor downregulation associated with alprazolam administration. Biochem. Pharmacol., 21, 3733-3777.

OLSEN, R.W. \& TOBIN, A.J. (1990). Molecular biology of GABA 
receptors. FASEB. J., 4, 1469-1480.

PRITCHETT, D.B., SONTHEIMER, H., SHIVERS, B.D., YMER, S., KET TENMAN, H., SCHOFIELD, P.R. \& SEEBURG, P.H. (1989). Importance of a novel $\mathrm{GABA}_{\mathbf{A}}$ receptor subunit for benzodiazepine pharamcology. Nature, 338, 582-584.

SCHOFIELD, P.R., DARLISON, M.G., FUJITA, N., BURT, D.R., STE PHENSON, F.A., RODRIGUEZ, H., RHEE, L.M., RAMACHANDIAN,
J., REALE, V., GLENCOURSE, T.A., SEEBURG, P.H. \& BARNARD, E.A. (1987). Sequence and functional expression of the GABA receptor shows a ligand-gated receptor superfamily. Nature, 328, 221-227.

TIETZ, E.I., ROSENBERG, H.C. \& CHIU, T.H. (1986). Autoradiographic localization of benzodiazepine receptor downregulation. J. Pharmacol. Exp. Ther., 236, 284-291.

(Received January 30, 1991 